\title{
Export-led growth hypothesis: Empirical evidence from the Southern African Customs Union countries
}

\author{
Malefa Rose Malefane
}

\begin{abstract}
A B S T R A C T
Objective: The objective of the article is to examine the export-led growth hypothesis in the Southern African Customs Union (SACU).

Research Design \& Methods: This study employs annual data on output, exports, imports, and a structural dummy variable for SACU countries, namely, South Africa, Botswana, Lesotho, Namibia, and eSwatini. The study applies the cointegration test based on the Johansen (1988) and the Johansen and Juselius (1990) approach, followed by the vector error correction model and the trivariate Granger causality analysis.

Findings: All SACU countries, apart from Lesotho, have witnessed a significant positive relationship between exports and economic growth during the reviewed period. In the case of Lesotho, the study finds a negative relationship between exports and economic growth. Causality results confirm that the export-led growth hypothesis is valid in Namibia and South Africa, but not in eSwatini, Botswana, and Lesotho.

Implications \& Recommendations: Based on the overall findings, this study mainly recommends that policymakers in SACU countries should consider providing extensive support for the development of infrastructure and trade-related logistics.

Contribution \& Value Added: SACU countries rely on a narrow range of exports, which could affect their vulnerability to external shocks. This article provides empirical evidence on whether data from SACU countries is consistent with the export-led growth hypothesis.

Article type: research article

Keywords: $\quad$ exports; imports; economic growth; SACU; Granger causality

JEL codes: $\quad$ F43, C13

Received: 16 June 2020

Revised: 22 December 2020 Accepted: 30 December 2020
\end{abstract}

Suggested citation:

Malefane, M.R. (2021). Export-led growth hypothesis: Empirical evidence from the Southern African Customs Union countries. Entrepreneurial Business and Economics Review, 9(2), 55-69. https://doi.org/10.15678/EBER.2021.090204

\section{INTRODUCTION}

Since the earlier works of Balassa (1978) and (1985), empirical research has continued to probe the relevance and validity of the export-led growth hypothesis in the context of the industrialised, developing, and least-developed economies. While there is growing evidence on the export-led growth hypothesis, one could argue that the adoption of the export-led growth industrialisation on its own does not guarantee the realisation of growth-enhancing benefits. Although the export-led growth strategy provides growth opportunities, differences in technology across countries imply that countries adopting this strategy are likely to face varying effects resulting from export-promoting policies (see for example, Feenstra, 2015). Thus, there is no guarantee that the export-promoting strategy will always result in a positive causal effect on long-run economic growth.

Despite the contentious debate around the role of export-led growth strategies in economic development, several reasons explain why exports matter in driving economic growth. One of the conventional views arising from theoretical presumptions is that exports could be the key drivers of economic growth. Building on the classical theoretical viewpoints, the proposition is that export expansion tends 
to cause a rise in output through improved productivity or large-scale production resulting from specialisation (Marin, 1992; Bahmani-Oskooee \& Economidou, 2009). Country-based experiences, however, suggest that structural characteristics affect the extent to which exports stimulate economic growth.

Against this backdrop, this article aims to examine the export-led growth hypothesis in the five Southern African Customs Union (SACU) countries based on their experiences over the past four decades. The study hypothesises that economic growth, measured by the annual growth rate in the real gross domestic product (GDP), is positively related to exports and imports. The other hypothesis is that export expansion leads to economic growth in SACU countries. The motivation behind the current study is that over the past four decades, SACU countries have been operating under the export promotion regime, which has replaced the previous import substitution industrialisation regime.

Earlier studies that examined the export-led growth hypothesis in SACU countries mostly did so without considering structural breaks that result from external shocks (see Sinoha-Lopete, 2006; Jordaan \& Eita, 2007; Bosupeng, 2015). In bridging the gap in SACU-related literature, the current study tests the significance of exports in promoting economic growth in the presence of structural changes emanating from external shocks. The study pursues these research questions: has the implementation of the exportoriented growth strategy boosted economic growth in SACU countries given the possible structural breaks? What country-specific factors affect the export-led growth strategy in SACU countries?

The novelty of the current study is two-fold - first, it provides a comparative analysis of SACU countries over the past four decades taking structural changes into account. The study also identifies major export commodities and factors that hinder export expansion from being translated into sustained economic growth as intended by the export-oriented policies that SACU countries have adopted. This article is organised as follows: after the introduction, the next section discusses literature review in which the study presents empirical evidence from developed and developing economies. Thereafter, the study provides an overview of the origins of the export-led growth strategy in the Sothern African Customs Union. The next section presents methodology and data, followed by the discussion of empirical findings. The last section concludes the study.

\section{LITERATURE REVIEW}

Various empirical studies on both developed economies and developing economies continue to probe the role of exports in economic growth. From these studies it emerges that while the proponents of export-led growth strategy favour export-promoting policies, export expansions per se do not always bring about significant growth effects. In some cases, the experiences surrounding export-led growth might be due to country-specific factors.

\section{Empirical evidence from developed countries}

Evidence from existing studies shows that export-led industrialisation applies to both developed and developing economies. In a study examining the export-led growth hypothesis in four industrialised countries, namely United States, Japan, Germany, and the United Kingdom, Marin (1992) finds that except for United Kingdom, exports, productivity, and terms-of-trade move together in the long run. The results further confirm that exports Granger- cause productivity in all four investigated countries.

In one of the studies focusing on the Southern European countries over the period 1960-2014, Konstantakopoulou (2016) employs the Pesaran, Shin, and Smith (2001) bound-testing approach to investigate the existence of a static and dynamic relationship between exports and economic growth. The study confirms a bidirectional Granger causality in Spain and Greece, but none for Italy. Moreover, the study establishes a unidirectional causality from exports to economic growth in Portugal.

Kónya (2008) employs the modified Wald statistics to determine the export-led growth hypothesis in twenty-five OECD countries. The findings show that there is no causality between exports and economic growth in Luxembourg and the Netherlands. The study finds a unidirectional causality from exports to economic growth in Iceland. The results also point to a bidirectional causality between exports and growth in Sweden and the United Kingdom. For some of the countries included in the study, the results are too controversial to arrive at unanimous conclusions. 
In another study, Henriques and Sadorsky (1996) investigate the export-led growth hypothesis in Canada. While the results confirm the existence of a long-run relationship between real exports, real GDP, and terms-of-trade, no evidence supporting the export-led growth hypothesis prevails. Most importantly, their results indicate that for Canada, changes in GDP growth precede changes in exports.

Shan and Sun (1998) examine the export-led growth hypothesis in China during 1987-1996. The results indicate that even though a positive relationship between exports and output exists in China, there is no unidirectional causality from exports to output, which rules out the validity of the exportled growth hypothesis.

In a study based in Norway, Nesset (2004) examines the link from growth in exports to productivity growth over 1968-1992. The empirical results indicate that economic growth is productivity-led and not export-led, which leads to the conclusion that Norway must consider giving more direct productivity stimulus including research and development, infrastructure, and education support.

Fountas (2000) tests the export-led growth hypothesis for Ireland using two sample periods: 19501990 and 1981-1994. The results show no evidence of export-led growth over the period 1950-1990. However, the results support the export-led growth hypothesis for the period 1981-1994 suggesting the importance of export promoting policies that the country has adopted.

\section{Empirical evidence from developing countries}

In a recent study conducted in Latin America, Arteaga, Cardozo, and Diniz (2020) examine the effects of exports to China and the world, given a structural break. For the period 2002-2017, the results show that exports to China boost economic growth in South America but are detrimental to Mexico, Central America, and the Caribbean.

In a study focusing on Fiji and Papua New Guinea, Narayan, Narayan, Prasad, and Prasad (2007) investigate the export-led growth hypothesis in the two countries that experienced dismal economic growth in the past. The study finds evidence of the export-led growth hypothesis in the long run in Fiji and some evidence of export-led growth in the short run in the case of Papua New Guinea.

Abual-Foul (2004) examines the relevance of the export-led growth hypothesis in Jordan over 1976-1997 using the vector autoregression and the error correction model. The results support the export-led growth hypothesis leading to the conclusion that the export-led growth strategy has promoted faster economic growth in Jordan.

Maneschiöld (2008) uses data for Argentina, Brazil and Mexico to analyse the export-led growth hypothesis, where the introduction of the NAFTA is treated as the structural break point. The study finds evidence of bi-directional or unidirectional causality from exports to GDP supporting the exportled growth hypothesis in the three investigated countries for the pre- and post-break periods.

Malhotra and Kumari (2016) investigate the validity of the export-led growth hypothesis in Bangladesh, India, Pakistan, and Sri Lanka over the period 1980-2012. The results confirm the export-led growth hypothesis in India, but not in Pakistan, Bangladesh, and Sri Lanka. In another study conducted in South East Asian countries, Shirazi and Abdul Manap (2005) confirm the export-led growth hypothesis in Bangladesh, Pakistan, and Nepal, but not in India and Sri Lanka.

Focusing on sub-Saharan Africa, Bbaale and Mutenyo (2011) investigate the relationship between export composition and output growth in a panel of 35 countries for the period 1988-2007. The findings indicate that growth-enhancing effect can be attributed to agricultural exports and not manufactured exports.

Considering some of the existing empirical evidence based on previous studies conducted in the Southern African Customs Union (SACU) countries, there is a lack of consensus on the relationship and causality between exports and economic growth. For instance, Bahmani-Oskooee and Economound (2009) could not establish the direction of the long-run relationship between exports and output growth in Lesotho and several other developing countries. On the contrary, their study found that increased exports cause economic growth in the long run in South Africa, Swaziland, and a few other African countries.

In another study focusing on several Southern African economies, Sinoha-Lopete (2006) examines the export-led hypothesis for 1980-2002. The results confirm the export-led growth hypothesis 
in Lesotho and eSwatini, but not in other countries related to the current study, which are Botswana, Namibia, and South Africa. In a country-based study focusing on Botswana, Bosupeng (2015) investigates the export-led hypothesis during 2003-2012. The findings reject the export-led growth hypothesis for Botswana.

\section{Export-led growth in SACU: an overview}

The 2002 SACU Agreement allows duty free importation of goods originating from the Common Customs Area although members can impose restrictions on trade where applicable. Under the Agreement, members can continue with pre-existing preferential arrangements, but goods admitted duty free under these preferential arrangements are liable to excise duties when exported to another SACU country (Southern African Customs Union, 2013).

Apart from the role played by SACU membership, the exchange rate arrangements in SACU also act as interlinkages in the sub-region. Under the Common Monetary Area (CMA) arrangement, all SACU countries except Botswana, have pegged their local currencies to the South African Rand (Stoykova, 2021). This implies that trade patterns in SACU are likely to follow fluctuations in the South African Rand. Again, South Africa is characterised by a large nontraded goods sector, which in turn determines the country's exchange rate (Makanza, 2015). For instance, in the face of macroeconomic shocks that affect relative prices, the real exchange (in South Africa in this case) will appreciate, causing prices in the domestic economy to be relatively higher than global prices.

The implication of South Africa's macroeconomic shocks for other CMA countries is that their relative prices are likely to follow the same trend as that of South Africa. In one of the studies related to this argument, Sendza and Diaba (2017) confirm a negative short-run impact of exchange rate volatility in South Africa over the period 1993 to 2014, and a positive impact in the long-run. During the period between 1993 and 2014, SACU countries witnessed an overall upward trend in their exports, apart from a slump in exports following the global financial crises of 2008/2009, which affected the major economies that trade with SACU countries (see SACU Annual Report; 2010, 2012 and 2015).

Looking at the transition in trade policy within the SACU countries over the past four decades, there is evidence of a radical regime shift from import substitution industrialisation to export-led strategy. In SACU, South Africa was among the first to implement the export-led strategy following the Reynders Commission of 1972 (see Bell, 1997). For Lesotho, the move away from the import-substituting industrialisation became vital in the national objectives. This has resulted in Lesotho's trade policy being more inclined towards stronger export orientation (World Trade Organisation, 1998). Although Botswana, Lesotho, Namibia, eSwatini, and South Africa adopted the export-led strategy at different points in time, each of these SACU countries has been operating under this new strategy for more than three decades. Hence, the expectation is that the regime shift to the export-led growth strategy should have benefited the SACU countries to some extent.

One prominent feature characterising the pattern of exports in SACU economies is that South Africa has been recording more exports than its SACU counterparts during the past years (Figure 1). As shown in Figure 1, the trends in exports for all the SACU countries during the period 1980 to 2018 are almost similar. The Figure shows that South Africa, followed by Botswana, surpassed other SACU countries in export performance during the reviewed period. Several reasons explain the differences in SACU countries. For Lesotho, the country still records the least exports compared to others in the customs union although its exports have picked up past the year 2000. The increase in Lesotho's exports is partly due to the Africa Growth and Opportunity Act (AGOA), which commenced in 2000. Under AGOA, Lesotho gains duty-free access to the United States in exports of clothing and textiles (see Malefane, 2007). For Namibia and eSwatini, the growth in exports was modest during the period under investigation as shown in Figure 1. One factor that has affected the exports in Namibia is slow growth in South Africa, the key trading partner for Namibia. Due to the slow growth in South Africa, the demand for Namibia's commodity exports has declined in recent years (United Nations, 2017). 


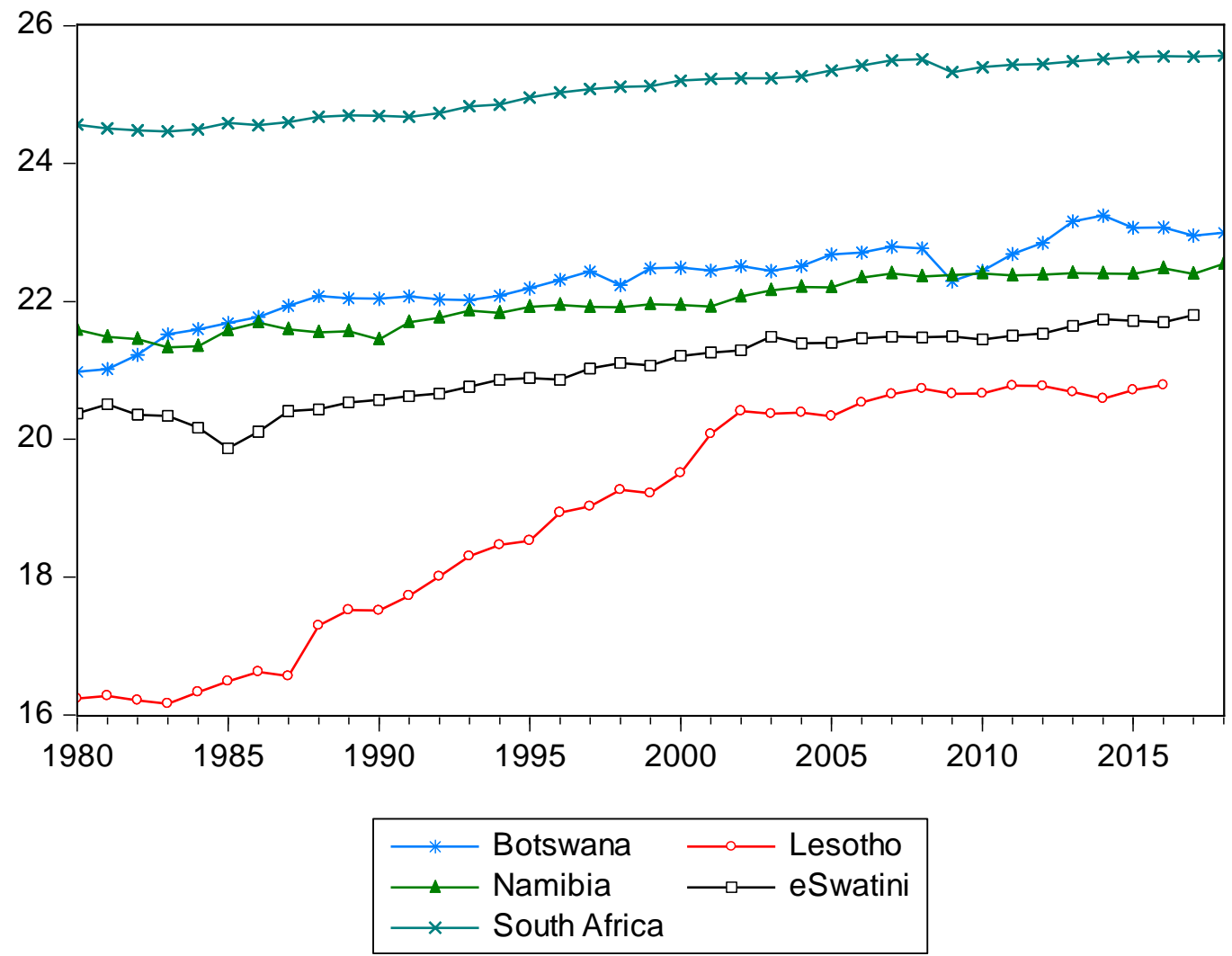

Figure 1. Trends in the log of real exports in SACU countries, (1980-2018) Source: constructed from World Development Indicators (2019).

SACU countries are vastly diverse in their economic structures, including sectoral policies, market size and export commodities. In one of the latest trade policy reviews of SACU countries, the World Trade Organisation (2015) remarked that SACU has intra-country inequalities, which are among the highest globally. Despite their diversities, SACU countries continue to implement economic and policy reforms aimed at sustainable growth, job creation, and industrial development. Table 1 presents a summary of the policy objectives and challenges in SACU countries during the period between 2015 and 2020. The summary highlights strategic policy objectives, adopted measures, principal exports, and main challenges facing the export sector. As it can be deduced from Table 1, while SACU countries have varied economic objectives and goals, they generally seek sustainable economic growth and enhanced private sector development to aid job creation and poverty alleviation. 
Table 1. Summary of economic developments and challenges in SACU countries

\begin{tabular}{|c|c|c|c|c|}
\hline Country & Aims of strategic policies & Adopted measures & $\begin{array}{l}\text { Principal } \\
\text { exports }\end{array}$ & Main challenges \\
\hline Botswana & $\begin{array}{l}\text { sustainable economic growth; } \\
\text { economic diversification; im- } \\
\text { proved public-private partner- } \\
\text { ship; accelerated private sec- } \\
\text { tor development; small and } \\
\text { medium-sized enterprise } \\
\text { (SME) development }\end{array}$ & $\begin{array}{l}\text { diversified production } \\
\text { by private sector; in- } \\
\text { stitutional support and } \\
\text { development; capacity } \\
\text { development pro- } \\
\text { gramme for SMEs }\end{array}$ & \begin{tabular}{|l|} 
diamonds; \\
machinery \\
and electrical \\
equipment; \\
salt and soda \\
ash; gold; ve- \\
hicles and \\
transport \\
equipment; \\
meat and \\
meat prod- \\
ucts
\end{tabular} & $\begin{array}{l}\text { weaker global diamond de- } \\
\text { mand; weak growth prospect } \\
\text { of South Africa }\end{array}$ \\
\hline Lesotho & $\begin{array}{l}\text { improved private sector } \\
\text { growth; inclusive and sustain- } \\
\text { able economic growth; infra- } \\
\text { structure and human capital } \\
\text { development; strengthening } \\
\text { of national governance and } \\
\text { accountability system }\end{array}$ & \begin{tabular}{|l|} 
reforms in land own- \\
ership system; im- \\
provements in the \\
business environment; \\
political governance \\
reforms
\end{tabular} & $\begin{array}{l}\text { textiles, } \\
\text { clothing, and } \\
\text { footwear; di- } \\
\text { amonds; wa- } \\
\text { ter }\end{array}$ & $\begin{array}{l}\text { lack of skill and capacity; de- } \\
\text { cline in textiles due to compe- } \\
\text { tition from Asian producers; } \\
\text { macroeconomic instability; in- } \\
\text { adequate and poor-quality in- } \\
\text { frastructure; weak human } \\
\text { capital and skill gap }\end{array}$ \\
\hline Namibia & $\begin{array}{l}\text { protection of intellectual } \\
\text { property; promotion of value- } \\
\text { added production; stimulation } \\
\text { of downstream agro-indus- } \\
\text { tries; improved competitive- } \\
\text { ness and contribution of agri- } \\
\text { culture industries }\end{array}$ & $\begin{array}{l}\text { upgrades in infor- } \\
\text { mation and technol- } \\
\text { ogy }\end{array}$ & $\begin{array}{l}\text { diamonds; } \\
\text { copper; ura- } \\
\text { nium ores } \\
\text { and concen- } \\
\text { trates }\end{array}$ & $\begin{array}{l}\text { narrow export base; capacity } \\
\text { constraints and shortage of } \\
\text { skilled labour force; less com- } \\
\text { petitive business environ- } \\
\text { ment; high production costs; } \\
\text { infrastructure bottlenecks }\end{array}$ \\
\hline $\begin{array}{l}\text { South } \\
\text { Africa }\end{array}$ & $\begin{array}{l}\text { sustainable economic growth; } \\
\text { job creation; reforming of } \\
\text { state-owned enterprises }\end{array}$ & $\begin{array}{l}\text { removal of barriers to } \\
\text { mining investment; re- } \\
\text { structuring of major } \\
\text { state-owned utility } \\
\text { company (Eskom); re- } \\
\text { viewing of visa re- } \\
\text { quirements to boost } \\
\text { the tourism industry; } \\
\text { allocation of telecom- } \\
\text { munications spec- } \\
\text { trum; creation of Spe- } \\
\text { cial Economic Zones }\end{array}$ & $\begin{array}{l}\text { gold; bitumi- } \\
\text { nous coal; } \\
\text { manganese } \\
\text { ores; diesel- } \\
\text { powered } \\
\text { trucks }\end{array}$ & $\begin{array}{l}\text { lack of adequate skills; inade- } \\
\text { quate domestic infrastruc- } \\
\text { ture; lack of competition in } \\
\text { goods and services market }\end{array}$ \\
\hline eSwatini & $\begin{array}{l}\text { food security; improved } \\
\text { productivity; diversification of } \\
\text { commercial agriculture; } \\
\text { strengthening of economic } \\
\text { governance; acceleration of } \\
\text { diversified, inclusive, and sus- } \\
\text { tainable growth }\end{array}$ & $\begin{array}{l}\text { improvements in coal } \\
\text { production; new legis- } \\
\text { lation on telecommu- } \\
\text { nications - independ- } \\
\text { ent regulation; scaling } \\
\text { up of infrastructure }\end{array}$ & \begin{tabular}{|l|} 
raw cane \\
sugar and \\
sugar-based \\
products; \\
chemical \\
products; co- \\
niferous \\
wood
\end{tabular} & $\begin{array}{l}\text { vulnerability to climate } \\
\text { change; limited economic } \\
\text { classification and market con- } \\
\text { centrations; capacity con- } \\
\text { straints and skills shortages; } \\
\text { deteriorating infrastructure }\end{array}$ \\
\hline
\end{tabular}

Source: own compilation based on World Trade Organisation (2015); African Development Bank - African Economic Outlook 2020; African Development Bank Country Strategy Papers (Online); Statistics Botswana (2020); Commonwealth of Nations; World Bank - World Integrated Trade Statistics (2020). 


\section{RESEARCH METHODOLOGY}

Influenced by literature and the focus of trade policies in SACU countries, the current study develops these hypotheses:

H1: There is a positive relationship between exports and output growth in SACU countries.

H2: There is a unidirectional causality from exports to output growth in SACU countries.

This study employs annual data for output $(\mathrm{Y})$, exports $(\mathrm{X})$, imports $(\mathrm{M})$, and structural dummy variable (DUM). The output variable is proxied by the log of real gross domestic product; exports are proxied by the log of real exports of goods and services; while imports are proxied by the log of real imports of goods and services. All values before the log transformation are at constant 2010 US\$. Due to variations in data availability, the study uses different sample periods in empirical investigation. For Botswana, the sample period is 1975-2018, while it is 1960-2017 for Lesotho, 1980-2018 for Namibia and eSwatini, and 1960-2018 for South Africa. The data is from the World Bank World Development Indicators (2019).

The study constructs a structural dummy variable based on Bai (1997) and Bai and Perron's (1998a, 2003) procedure to capture the external shocks. The results of the multiple breakpoint tests are reported in the Appendix. The study did not construct any structural break dummy for Namibia since the structural break tests failed to confirm any significant structural breaks for the country. Based on Multiple breakpoint test results, the values for the dummy variable (DUM) for other SACU countries are as follows:

In the Botswana dataset, DUM takes value 1 in 1991 and 2009; 0 otherwise.

In the Lesotho dataset, DUM takes value 1 in 1977, 1998, and 2009; 0 otherwise.

In the eSwatini dataset, the value of DUM is 1 in 1985 and 2010; 0 otherwise.

In South Africa's dataset, DUM takes value 1 in 1977, 1985, and 2000; 0 otherwise.

Given the tendency of economic variables to follow random walks, the study tested the unit root using the Augmented Dickey-Fuller (ADF) test and the Kwiatkowski-Phillips-Schmidt-Shin (KPSS) test. The null hypothesis for the KPSS test is that the series are stationary while the null hypothesis for the ADF test null hypothesis is that the series are non-stationary.

The study performed the cointegration test based on Johansen (1988) and Johansen and Juselius (1990). The advantage of the Johansen's approach is that it tests the null hypothesis of no cointegration against the alternative of one or more cointegrating vectors. The unrestricted vector autoregression (VAR) was specified as follows:

$$
X_{t}=A_{0}+\sum_{j=1}^{p} A_{j} X_{t-j}+\varepsilon_{t}
$$

where:

$X_{t}$ - vector of ( $\left.m X 1\right)$ nonstationary variables - output, exports and imports;

$A_{j}-(m X m)$ matrix of unknown parameters;

$p$ - lag length;

$\varepsilon_{t}-(m X 1)$ vector of disturbance terms.

The Akaike information criterion (AIC) and the Schwarz criterion (SC) determined the maximum lag length. The maximum lag length for Botswana, Namibia, and South Africa is two (2), while it is one (1) for Lesotho and eSwatini.

The vector error correction model (VECM) specification of this study is:

$$
\Delta X_{t}=\mu+\sum_{j=1}^{p-1} \Gamma_{j} \Delta X_{t-j}+\Pi X_{t-i}+\varepsilon_{t}
$$

where:

$\mu$ - (mX 1) vector of constant terms;

$\Gamma, \Pi$ - coefficient matrices;

$\Delta$ - difference operator. 
The study used a VAR Granger causality to determine the direction of causality between output, exports, and imports in the face of the structural changes.

Table 2. List of variables used in the analysis

\begin{tabular}{|c|c|c|}
\hline Variable & Indicator & Source (the code of dataset) \\
\hline Output (Y) & Real gross domestic product, constant 2010 US\$ & $\begin{array}{l}\text { World Development Indicators, } \\
2019 \text { (NY.GDP.MKTP.KD) } \\
\end{array}$ \\
\hline Imports (M) & Imports of goods and services, constant 2010 US\$ & $\begin{array}{l}\text { World Development Indicators, } \\
2019 \text { (NE.IMP.GNFS.KD) }\end{array}$ \\
\hline Imports (X) & Exports of goods and services, constant 2010 US\$ & $\begin{array}{l}\text { World Development Indicators, } \\
2019 \text { (NE.EXP.GNFS.KD) }\end{array}$ \\
\hline $\begin{array}{l}\text { Structural dummy } \\
\text { (DUM) }\end{array}$ & $\begin{array}{l}\text { Dummy variable capturing structural changes. } \\
\text { Value } 1 \text { if there is structural change; } 0 \text { otherwise }\end{array}$ & $\begin{array}{l}\text { Own computation based on Multiple } \\
\text { breakpoint tests }\end{array}$ \\
\hline
\end{tabular}

Source: own elaboration based on World Bank World Development Indicators (2019).

\section{Discussion of Results}

As part of the empirical investigation, the study tested output, exports, and imports for a unit root, and Table 3 reports the results. The results from the ADF and KPSS tests show that, generally, the variables used in this study are first-difference stationary or are integrated of order one.

Table 3. Unit root test results

\begin{tabular}{|c|c|c|c|c|c|c|c|c|}
\hline \multirow{3}{*}{ Variable } & \multicolumn{4}{|c|}{ ADF Test } & \multicolumn{4}{|c|}{ KPSS Test } \\
\hline & \multicolumn{2}{|c|}{ Log levels } & \multicolumn{2}{|c|}{ First difference } & \multicolumn{2}{|c|}{ Log levels } & \multicolumn{2}{|c|}{ First difference } \\
\hline & No trend & Trend & No trend & Trend & No trend & Trend & No trend & Trend \\
\hline Y_BWA & $-4.90 * * *$ & -1.63 & - & $-5.77 * * *$ & $0.82 * * *$ & $0.21 * *$ & $0.71 * *$ & 0.10 \\
\hline M_BWA & -1.46 & $-3.67 * *$ & $-5.12 * * *$ & - & $0.82 * * *$ & 0.08 & 0.11 & 0.04 \\
\hline X_BWA & $-2.71 *$ & -2.56 & - & $-5.46 * * *$ & $0.79 * * *$ & $0.20 * *$ & 0.32 & 0.08 \\
\hline Y_LSO & -1.97 & -2.02 & $-7.76 * * *$ & $-8.14 * * *$ & $0.85^{* * *}$ & $0.15^{* *}$ & 0.32 & $0.50 * * *$ \\
\hline M_LSO & $-5.25 * * *$ & -1.12 & - & $-6.44 * * *$ & $0.78 * * *$ & $0.21 * *$ & 0.85 & 0.12 \\
\hline X_LSO & -1.99 & -0.64 & $-6.05 * * *$ & $-6.51 * * *$ & $0.79 * * *$ & $0.16 * *$ & $0.39 *$ & 0.12 \\
\hline Y_NAM & 1.30 & -3.06 & $-4.21 * * *$ & $-4.29 * * *$ & $0.74^{* * *}$ & 0.20 & $0.38^{*}$ & 0.12 \\
\hline M_NAM & 0.30 & $-3.64 * *$ & $-4.58 * * *$ & - & $0.70 * *$ & 0.20 & 0.22 & $0.18^{* *}$ \\
\hline X_NAM & -0.30 & $-3.64 * *$ & $-6.19 * * *$ & - & $0.73 * *$ & 0.09 & 0.17 & 0.12 \\
\hline Y_SWZ & $-3.75 * * *$ & -1.62 & $-4.01 * * *$ & $-4.96 * *$ & $0.73 * *$ & $0.17^{* *}$ & 0.51 & 0.06 \\
\hline M_SWZ & -0.90 & -3.04 & $-4.20 * * *$ & $-4.08 * * *$ & 0.66 & 0.09 & 0.06 & 0.05 \\
\hline X_SWZ & -0.86 & $-3.57 * *$ & $-5.80 * * *$ & $\ldots$ & $0.70 * * *$ & 0.11 & 0.86 & 0.04 \\
\hline Y_ZAF & -0.17 & -1.87 & $-4.14 * * *$ & $-4.09 * * *$ & $0.73 * *$ & $0.16^{* *}$ & \begin{tabular}{|l|}
0.14 \\
\end{tabular} & $0.12 *$ \\
\hline M_ZAF & -0.33 & -2.31 & $-5.67 * * *$ & $-5.60 * * *$ & $0.72 * *$ & 0.11 & 0.09 & 0.09 \\
\hline X_ZAF & -0.30 & -2.17 & $-5.67 * * *$ & $-5.59 * * *$ & $0.73 * *$ & $0.15^{* *}$ & 0.13 & $0.13^{*}$ \\
\hline
\end{tabular}

Source: own computations. * ${ }^{* *}$ and $* * *$ represent significance level at $10 \%, 5 \%$ and $1 \%$ respectively. BWA, LSO, NAM, SWZ, and ZAF represent Botswana, Lesotho, Namibia, eSwatini, and South Africa. Y, M, X respectively denote output, imports, and exports.

\section{Cointegration test results}

After confirming the order of integration, the cointegration test was performed. Table 4 shows the results of the trace statistic and the maximum eigen-value statistic ( $\lambda$-Max). The test statistics indicate the hypothesised number of cointegrating vectors for each one of the five countries under empirical investigation. 
Table 4. Johansen cointegration test results

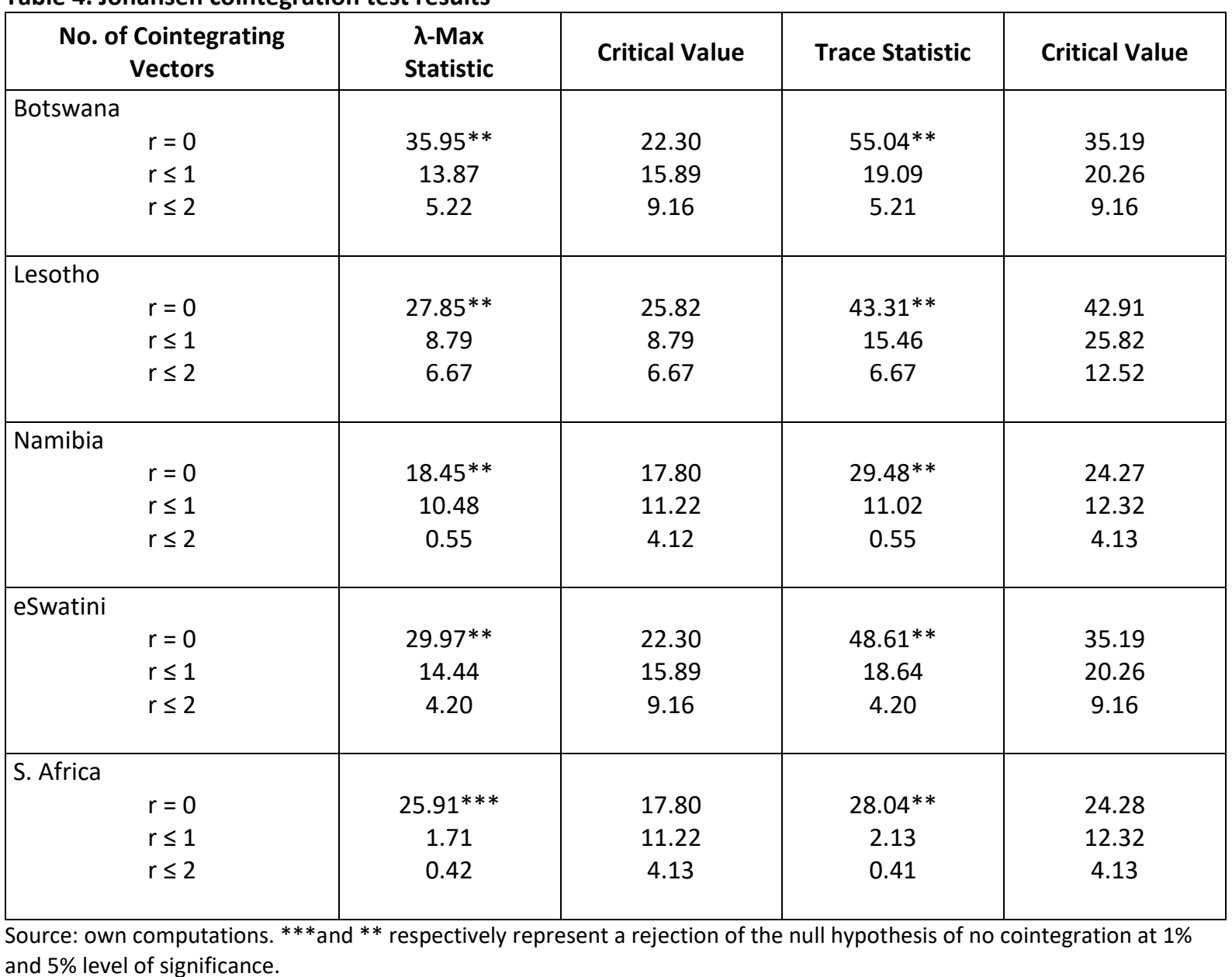

The results in Table 4 indicate the rejection of the null hypothesis of no cointegration, and further point to one cointegrating vector in each one of the SACU countries. The confirmation of a cointegrating relationship allows the estimation of the vector error correction model (VECM). For Botswana, the study estimates the model with an intercept but no trend in the cointegrating equation (CE) and VAR. In the case of eSwatini, the study estimates the model with an intercept but no trend in cointegrating equation (CE), and no intercept in VAR. For Lesotho, the study estimates the model with intercept and trend in CE but no trend in VAR. For Namibia and South Africa, the study estimates the model with no intercept or trend in CE or VAR.

Table 5 reports the estimation results in which the regressors $X$ and $M$ in Panel $A$ of the table are in levels, while $\Delta \mathrm{Y}_{\mathrm{t}-1}, \Delta \mathrm{Y}_{\mathrm{t}-2}, \Delta \mathrm{X}_{\mathrm{t}-1}, \Delta \mathrm{X}_{\mathrm{t}-2}, \Delta \mathrm{M}_{\mathrm{t}-1}$ and $\Delta \mathrm{M}_{\mathrm{t}-2}$ in Panel $\mathrm{B}$ are in the first difference. 
Table 5. Summary of the estimation results

\begin{tabular}{|c|c|c|c|c|c|}
\hline \multicolumn{6}{|c|}{ Panel A: Long-run results } \\
\hline Regressor & Botswana & Lesotho & Namibia & eSwatini & South Africa \\
\hline$x$ & $\begin{array}{c}0.58 * * * \\
(6.98)\end{array}$ & $\begin{array}{c}-0.09 * * * \\
(-3.03)\end{array}$ & $\begin{array}{c}0.77 * * * \\
(16.28) \\
\end{array}$ & $\begin{array}{c}7.19 * * * \\
(3.89) \\
\end{array}$ & $\begin{array}{c}1.85^{* * *} \\
(8.61)\end{array}$ \\
\hline M & $\begin{array}{c}0.34 * * * \\
(4.02)\end{array}$ & $\begin{array}{c}0.18 * * * \\
(6.87)\end{array}$ & $\begin{array}{c}0.28 * * * \\
(5.73)\end{array}$ & $\begin{array}{c}-8.23 * * * \\
(-4.201)\end{array}$ & $\begin{array}{c}-0.80 * * * \\
(-3.67)\end{array}$ \\
\hline @Trend(60) & $\ldots$ & $\begin{array}{c}-0.03 * * * \\
(-7.79)\end{array}$ & $\cdots$ & $\ldots$ & $\cdots$ \\
\hline Constant & $\begin{array}{c}-2.59 * * * \\
(-3.47)\end{array}$ & $\begin{array}{c}-17.90 \\
\ldots \\
\end{array}$ & $\begin{array}{c}0.28 * * * \\
(5.73)\end{array}$ & $\begin{array}{c}-83.88 * * * \\
(5.42)\end{array}$ & $\cdots$ \\
\hline \multicolumn{6}{|c|}{ Panel B: Short-run results } \\
\hline Regressor & Botswana & Lesotho & Namibia & eSwatini & South Africa \\
\hline$\Delta \mathrm{Y}_{\mathrm{t}-1}$ & $\begin{array}{c}0.21 \\
(0.73)\end{array}$ & $\begin{array}{c}0.35 * * * \\
(2.97)\end{array}$ & $\begin{array}{c}0.42 * * \\
(2.50)\end{array}$ & $\begin{array}{c}0.01 \\
(0.05)\end{array}$ & $\begin{array}{c}0.90 * * * \\
(3.72)\end{array}$ \\
\hline$\Delta \mathrm{Y}_{\mathrm{t}-2}$ & $\begin{array}{c}0.12 \\
(0.42) \\
\end{array}$ & $\cdots$ & $\begin{array}{c}0.15 \\
(0.92) \\
\end{array}$ & $\cdots$ & $\begin{array}{c}-0.49 * * \\
(-2.19)\end{array}$ \\
\hline$\Delta \mathrm{X}_{\mathrm{t}-1}$ & $\begin{array}{c}-0.08 \\
(-0.96)\end{array}$ & $\begin{array}{c}0.01 \\
(0.17)\end{array}$ & $\begin{array}{c}-0.03 \\
(-0.44)\end{array}$ & $\begin{array}{c}-0.02 \\
(-0.30)\end{array}$ & $\begin{array}{c}-0.06 \\
(-1.00)\end{array}$ \\
\hline$\Delta \mathrm{X}_{\mathrm{t}-2}$ & $\begin{array}{c}-0.10 \\
(-1.32)\end{array}$ & $\cdots$ & $\begin{array}{c}-0.10 \\
(-1.77) \\
\end{array}$ & $\cdots$ & $\begin{array}{c}-0.04 \\
(-0.78) \\
\end{array}$ \\
\hline$\Delta \mathrm{M}_{\mathrm{t}-1}$ & $\begin{array}{c}0.03 \\
(0.46) \\
\end{array}$ & $\begin{array}{c}0.04 \\
(0.63)\end{array}$ & $\begin{array}{c}0.01 \\
(0.25) \\
\end{array}$ & $\begin{array}{c}0.04 \\
(0.45)\end{array}$ & $\begin{array}{c}-0.10 * * \\
(-2.31)\end{array}$ \\
\hline$\Delta \mathrm{M}_{\mathrm{t}-2}$ & $\begin{array}{c}0.05 \\
(0.77) \\
\end{array}$ & $\cdots$ & $\begin{array}{c}-0.17 * * * \\
(-2.78)\end{array}$ & $\cdots$ & $\begin{array}{c}0.02 \\
(0.62) \\
\end{array}$ \\
\hline DUM & $\begin{array}{c}-0.09 * * * \\
(-2.65)\end{array}$ & $\begin{array}{l}-0.01 \\
(0.26)\end{array}$ & $\cdots$ & $\begin{array}{l}-0.01 \\
(0.01)\end{array}$ & $\begin{array}{c}-0.04 * * * \\
(--3.04)\end{array}$ \\
\hline $\mathrm{ECT}_{\mathrm{t}-1}$ & $\begin{array}{c}-0.17^{* * *} \\
(-2.68)\end{array}$ & $\begin{array}{c}-0.64 * * * \\
(-5.60)\end{array}$ & $\begin{array}{c}-0.27^{* * *} \\
(-3.21)\end{array}$ & $\begin{array}{c}-0.02 * * * \\
(-4.73) \\
\end{array}$ & $\begin{array}{c}-0.05 * * * \\
(-4.70)\end{array}$ \\
\hline $\mathbf{R}^{2}$ & 0.38 & 0.44 & 0.27 & 0.36 & 0.58 \\
\hline F-statistic & $2.84 * *$ & $7.59 * *$ & 1.77 & $4.49 * *$ & $9.52 * *$ \\
\hline
\end{tabular}

Note: T-statistics are in parentheses. ${ }^{* * *}$ indicates a significance level at $1 \% ;{ }^{* *}$ indicates a significance level at $5 \%$. Source: own study.

Table 5 Panel A shows that there is a positive long-run relationship between exports and economic growth in Botswana, Namibia, eSwatini, and South Africa, and a negative relationship in Lesotho. The positive role of exports on economic growth has been echoed in other regions outside Africa. For instance, Hagemeger and Mućk (2019) found that exports played a major role in improving economic growth in Central and Eastern Europe during the period 1995 to 2014. In the case of Lesotho, however, the indication from the current results is that while other SACU countries have witnessed a positive role of exports on economic growth, Lesotho has had a different experience. These findings are an indication that the export-led growth strategy has not been successful in Lesotho, which could be linked to the country's low level of economic development and poor living standards relative to other SACU countries (see United Nations, Human Development Report, 2019).

The error correction model results from Table 5 Panel B show a negative and significant coefficient of the lagged error-correction ( $\left.\mathrm{ECT}_{\mathrm{t}-1}\right)$ in all the countries. An error term that is negative and statistically significant confirms convergence towards long-run equilibrium. Based on the coefficient of $E C T_{t-1}$, this study concludes that the speed of adjustment to deviations from long-run equilibrium is higher in Lesotho than in other SACU countries. The results show that about $64 \%$ of errors from the past are corrected in Lesotho, whereas eSwatini and South Africa exhibit a much slower adjustment. 
The results also show that the structural break dummy variable (DUM) has a significant negative effect on economic growth in Botswana and South Africa but has an insignificant impact in other SACU countries. A possible explanation for these results is that both South Africa and Botswana rely on exports of the mining sector, which are quite vulnerable to external shocks. Specifically, South Africa is a principal exporter of gold, while Botswana is a major exporter of diamonds. Observing the trends in past data, there is evidence that external shocks or global economic crises tend to cause a slump in export demand. Considering Botswana, for instance, the global financial crisis of 2009 exacerbated the country's vulnerability to external shocks given the country's heavy reliance on one major commodity, namely, diamonds (African Development Bank, 2020).

In the next step of the analysis, the study reports the results of the VAR Granger causality test to establish the direction of causality between output, exports, and imports, which are reported in Table 6.

Table 6. Results of the VAR Granger causality test

\begin{tabular}{|l|c|c|c|c|}
\hline \multirow{2}{*}{ Country } & \multirow{2}{*}{$\begin{array}{c}\text { Dependent } \\
\text { Variable }\end{array}$} & \multicolumn{3}{|c|}{ Source of causality } \\
\cline { 3 - 5 } & Output & Output & Exports & Imports \\
\hline Botswana & Exports & $5.53^{*}$ & 0.37 & 0.96 \\
& Imports & $7.04^{* *}$ & - & 0.91 \\
& Output & - & 0.95 & $3.58^{*}$ \\
& Exports & 0.02 & 0.01 & $3.90^{* *}$ \\
& Imports & 0.07 & - & - \\
\hline Lesotho & Output & - & $4.14^{* *}$ & 0.25 \\
& Exports & $11.82^{* * *}$ & - & $7.75^{* * *}$ \\
& Imports & 2.14 & 1.73 & - \\
\hline eSwatini & Output & - & 1.36 & $5.20^{* *}$ \\
& Exports & $4.85^{* *}$ & - & 0.06 \\
& Imports & 0.54 & 0.43 & - \\
\hline South Africa & Output & - & $13.53^{* * *}$ & $16.74^{* * *}$ \\
& Exports & 4.40 & - & $6.28^{* *}$ \\
\hline
\end{tabular}

Source: own computations of estimation results based on data from World Development Indicators (2019). ${ }^{*}, * *$, and ${ }^{* * *}$ denote significance level for Wald Statistics at $10 \%, 5 \%$ and $1 \%$ respectively. Values in the Table represent the computed Wald statistics.

The causality results in Table 6 suggest that there is export-led growth in Namibia and South Africa, but not in Botswana, eSwatini, and Lesotho. Namibia's results are consistent with Jordaan and Eita (2007). Their study confirmed the validity of the export-led growth hypothesis in Namibia. Similarly, the results for Lesotho and South Africa are consistent with Bahmani- Oskooee and Economound (2009). Their study found evidence of the export-led growth hypothesis in South Africa and a few other African countries but could not establish the direction of the long-run relationship between exports and economic growth in Lesotho.

There are different possible factors behind the varied experiences of SACU countries concerning the export-led growth hypothesis. One possible reason is that export-led growth in South Africa is likely to have resulted from the country's export base, which is more diversified than is the case with other SACU countries. In Namibia, significant export-led growth could be because while the country suffers from a narrow export base, its exports are not so vulnerable to external shocks as confirmed by the results from structural break tests discussed earlier in this article (also see the Appendix).

Another observation from causality results is that though this study could not confirm the export-led growth in Botswana, the results are consistent with Bosupeng (2015). That study revealed that economy of Botswana is driven by growth-led dynamics and not by export-led growth. Compared to the results from other studies conducted in developed countries, the results for this study are not different. Evidence from 
some of the previous studies shows that although exports and output could be positively related, sometimes there is no unidirectional causality from exports to output, which rules out the validity of the exportled growth hypothesis (see Konstantakopoulou, 2016; Nesset, 2008; Shan \& Sun, 1998).

\section{CONCLUSIONS}

The Southern African Customs Union (SACU) economies have switched the focus for their trade and industrialisation strategy from import substitution to export orientation for quite some time. However, whether SACU countries have realised significant growth effects from implementing export-oriented policies is controversial. This article revisits the export-led growth hypothesis debate in the Southern African Customs Union area, given the structural breaks. As is the case in several other emerging economies, exports from SACU countries have found it even more difficult to reach international markets due to a decline in export demand following the global economic crisis. Given the effect of the global economic crisis and structural changes on export demand, this article extends the empirical investigation by incorporating a structural dummy variable in the analysis.

The empirical results indicate a positive long-run relationship between exports and economic growth in Botswana, Namibia, eSwatini, and South Africa, but not for Lesotho. Lesotho's results show a significant negative relationship between exports and economic growth during 1960-2019. These puzzling results could be due to Lesotho's economic development that has probably affected the country's export potential. According to the United Nations Classification (2018), Lesotho is the only country in the SACU area that is a Least Developed Country (LDC). From these results, this study maintains that the effective implementation of export-oriented policies in developing economies must be accompanied by measures that reinforce trade capacity but also tackle the developmental challenges. Such measures could involve enhanced collaboration with external donors and other independent agencies that could assist with aspects like the widening of markets for SACU economies.

The causality results show that the export-led growth hypothesis holds in Namibia and South Africa, but not in Botswana, Lesotho, and eSwatini. The overall results of this study pose critical implications for SACU countries. First, there is a need to identify and address the factors that could have obstructed the export-led growth strategy in Lesotho. For all SACU economies, there is a need to address the constraints such as narrow export base, lack of skills, and inadequate infrastructure.

The second implication arising from the results is that in light of harnessing freer trade activities in the union and the African continent, SACU members could identify alternative measures that could aid the successful implementation of export-oriented policies. This recommendation requires SACU countries to develop alternative structures that aim at promoting partnerships while also ensuring the removal of potential barriers to trade-led growth.

It is advisable for policymakers in SACU countries to support infrastructure development and trade-related logistics to benefit the member countries. On this recommendation, this study admits that it could take several years to change some of the structural impediments of SACU countries, such as undiversified exports and skills shortages. Nevertheless, SACU countries could still find alternative ways to fast-track improvements in technology and skills development to bring about harmonious export-oriented industry.

This study is not free of limitations. The study does not explore the export-led growth hypothesis at a sectoral level. Future studies could benefit from investigating the major economic sectors.

\section{REFERENCES}

Abual-Foul, B. (2004). Testing the export-led growth hypothesis: evidence from Jordan. Applied Economics Letters, 11(6), 393-396, https://doi.org/10.1080/1350485042000228268

African Development Bank. (2019). Botswana Country Strategic Paper 2015-2019. Retrieved from https://www.afdb.org/en/documents/document/botswana-country-strategy-paper-2015-2019-108788 on May 2, 2020. 
African Development Bank. 2020. African Economic Outlook. Retrieved from https://www.afdb.org/en/newskeywords/african-economic-outlook-2020 on May 2, 2020.

Arteaga, J.C., Cardozo, M.L., \& Diniz, M.J.T. (2020). Exports to China and economic growth in Latin America, unequal effects within the region. International Economics, 164, 1-17. https://doi.org/10.1016/j.inteco.2020.06.003

Bahmani-Oskooee, M., \& Economidou, C. (2009). Export-Led Growth vs. Growth Led Exports: LDCs Experience. The Journal of Developing Areas, 42(2), 179-212. https://doi.org/10.1353/jda.0.0030

Balassa, B. (1978). Exports and economic growth. Journal of Development Economics, 5(2), 181-189. https://doi.org/10.1016/0304-3878(78)90006-8

Balassa, B. (1985). Exports, policy choices, and economic growth in developing countries after the 1973 oil shock. Journal of Development Economics, 18(1), 23-35. https://doi.org/10.1016/0304-3878(85)90004-5

Bbaale, E., \& Mutenyo, J. (2011). Export Composition and Economic Growth in Sub-Saharan Africa: A Panel Analysis. Consilience: The Journal of Sustainable Economy, 6(1), 1-19. Retrieved from https://www.jstor.org /stable/26167814 on May 2, 2020.

Bell, T. (1997). Trade Policy. In J. Michie \& V. Padayachee (Eds.), The Political Economy of South Africa's Transition (pp. 71-88). London: Dryden Press.

Bosupeng, M. (2015). The Export-Led Growth Hypothesis: New Evidence and Implications. Munich Personal RePEc Archive (MRPA) Paper No. 77917. Retrieved from https://mpra.ub.uni-muenchen.de/77917/ on April 2, 2020.

Commonwealth of Nations. (undated). Find import and export expertise in Lesotho. Retrieved from http://www.commonwealthofnations.org/sectors-lesotho/business/import_and_export/ on April 2, 2020.

Fountas, S. (2000). Some evidence on the export-led growth hypothesis for Ireland. Applied Economics Letters, 7(4), 211-214. https://doi.org/10.1080/135048500351528

Feenstra, R.C. (2015). Advanced international trade: theory and evidence. Princeton University Press.

Hagemejer, J., \& Mućk, J. (2019). Export-led growth and its determinants: Evidence from Central and Eastern European countries. The World Economy, 42(7), 1994-2025. https://doi.org/10.1111/twec.12790

Henriques, I., \& Sadorsky, P. (1996). Export-led growth or growth-driven exports? The Canadian case. The Canadian Journal of Economics, 29(3), 540-555. https://doi.org/10.2307/136249

Johansen, S. (1988). Statistical analysis of cointegrating vectors. Journal of Economic Dynamics and Control, 12, 231-54. https://doi.org/10.1016/0165-1889(88)90041-3

Johansen, S., \& Juselius, K. (1990). Maximum likelihood and inference on cointegration: with applications to the demand for money. Oxford Bulletin of Economics and Statistics, 52, 169-210. Retrieved from https://digidownload.libero.it/rocco.mosconi/JohansenJuselius1990.pdf on April 2, 2020.

Jordaan, A.C., \& Eita, J.H. (2007). Export and economic growth in Namibia: a Granger causality analysis. South African Journal of Economics, 75(3), 540-547. https://doi.org/10.1111/j.1813-6982.2007.00132.x

Kónya, L. (2004). Export-led growth, growth-driven export, both or none? Granger causality analysis on OECD countries. Applied Econometrics and International Development, 4(1), Retrieved from https:// papers.ssrn.com/sol3/papers.cfm?abstract_id=1231926\# on April 2, 2020.

Konstantakopoulou, I. (2016). New evidence on the Export-led-growth hypothesis in the Southern Euro-zone countries (1960-2014). Economics Bulletin, 36(1), 429-439. Retrieved from http://www.accessecon.com/Pubs/EB/2016/Volume36/EB-16-V36-I1-P44.pdf on April 2, 2020.

Malefane, M.R. (2007). Determinants of Foreign Direct Investment in Lesotho: Evidence from Cointegration and Error Correction Modelling. South African Journal of Economic and Management Sciences, 10(1), 99-106.

Malhotra, N., \& Kumari, D. (2016). Revisiting export-led growth hypothesis: an empirical study on South Asia. Applied Econometrics and International Development, 16(2), 157-168. Retrieved from https://www.usc.gal/economet/reviews/aeid16212.pdf on April 2, 2020.

Makanza, C.S. (2016). The Role of Non-Traded Goods in Current Account and Exchange Rate Determination: A DSGE Analysis (No. 2016-04). School of Economics, University of Cape Town.

Maneschiöld, P-O. (2008). A note on the export-led growth hypothesis: a time series approach. Cuadernos de Economía / Latin American Journal of Economics, 54(132), 293-302. Retrieved from https://scielo.conicyt.cl/scielo.php?pid=S0717-68212008000200006\&script=sci_arttext on April 2, 2020. 
Marin, D. (1992). Is the export-led growth hypothesis valid for industrialised countries?. The Review of Economics and Statistics, 74(4), 678-688. https://doi.org/10.2307/2109382

Mevel, S., \& Karingi, S. (2012). Deepening regional integration in Africa: A computable general equilibrium assessment of the establishment of a Continental Free Trade Area followed by a Continental Customs Union. Selected paper for Presentation at the 7th African Economic Conference. 30 October - 2 November 2012. Kigali: Rwanda.

Narayan, P.K., Narayan, S., Prasad. B.C., \& Prasad, A. (2007). Export-led growth hypothesis: evidence from Papua New Guinea and Fiji. Journal of Economic Studies, 34(4), 341-351. https://doi.org/10.1108/01443580710826380

Nesset, E. (2004). Exports and productivity in a small open economy: a causal analysis of aggregate Norwegian data. Journal of Policy Modeling, 26(1), 145-150. https://doi.org/10.1016/j.jpolmod.2003.10.004

Sendza, B., \& Diaba, D.D. (2017). Effect of exchange rate volatility on trade in Sub-Saharan Africa. Journal of African Trade, 4(1-2), 20-36. Retrieved from https://www.atlantis-press.com/journals/jat/125905676 on April 2, 2020.

Shan, J., \& Sun, F. (1998). On the export-led growth hypothesis: the econometric evidence from China. Applied Economics, 30(8), 1055-1065. https://doi.org/10.1080/000368498325228

Sinoha-Lopete, R. (2006). Export-led growth in Southern Africa. Louisiana University Masters Thesis. Retrieved from https://digitalcommons.Isu.edu/gradschool_theses?utm_source=digitalcommons.Isu.edu\%2Fgradschool_theses\%2F1531\&utm_medium=PDF\&utm_campaign=PDFCoverPages on April 2, 2020.

Shirazi, N.S., \& Abdul Manap, T.A. (2005). Export-led growth hypothesis: further econometric evidence from South Asia. The Developing Economies, XLIII(4), 472-488. https://doi.org/10.1111/j.1746-1049.2005.tb00955.x

South African Customs Union (SACU). (2010). Annual Report. Windhoek: South African Customs Union. Retrieved from https://www.sacu.int/docs/reports_annual/2009/annual-report09-10.pdf on April 2, 2020.

South African Customs Union (SACU). (2012). Annual Report. Windhoek: South African Customs Union. Retrieved from https://www.sacu.int/docs/reports_annual/2012/annualreport2012.pdf on April 2, 2020.

South African Customs Union (SACU). (2015). Annual Report. Windhoek: South African Customs Union. Retrieved from http://www.sacu.int/docs/reports_annual/2015/annual_report.pdf on April 15, 2020.

Statistics Botswana. (2020). Botswana's Principal Exports Composition. Retrieved from https://www.statsbots.org.bw/principal-export-composition on April 2, 2020.

Stoykova, O.I. (2021). How to increase the value of bilateral trade? Currency union versus fixed exchange rate regime. Entrepreneurial Business and Economics Review, 9(2), 21-38. https://doi.org/10.15678/EBER.2021.090202

United Nations. (2017). Economic profile: Namibia. Retrieved from https://www.uneca.org/publications on April 2, 2020.

United Nations. (2018). List of least developed nations. Retrieved from https://www.un.org/development/desa/dpad/wp-content/uploads/sites/45/publication/ldc_list April 2, 2020.

United Nations Development Programme. (2019). Human Development Report. Retrieved from http://hdr.undp.org/sites/default/files/hdr2019.pdf on April 2, 2020.

World Bank. (2019). World Development Indicators. Washington D.C: World Bank.

World Bank. (Online). World Integrated Trade Solutions: eSwatini Trade. Retrieved from https://wits.worldbank.org/countrysnapshot/en/SWZ on April 15, 2020.

World Bank. (Online). World Integrated Trade Solutions: Namibia Trade. Retrieved from https://wits.worldbank.org/CountryProfile/en/NAM on April 19, 2020.

World Bank. (Online). World Integrated Trade Solutions: South Africa Trade. Retrieved from https://wits.worldbank.org/countrysnapshot/en/ZAF on April 2, 2020.

World Trade Organisation (WTO). (1998). Trade Policy Review: Kingdom of Lesotho. WT/TPR/S/36. Geneva: World Trade Organisation.

World Trade Organisation (WTO). (2014). Annual Report. Geneva: World Trade Organisation.

World Trade Organisation (WTO). (2015). Trade Policy Review SACU. Geneva: World Trade Organisation. 


\section{Appendix A:}

Table A1. Results of the multiple breakpoint tests

\begin{tabular}{|l|c|c|c|c|}
\hline \multicolumn{1}{|c|}{ Country } & Sequence & Break dates & Scaled F-statistic & Critical value \\
\hline Botswana & 1 & 2009 & $61.67^{*}$ & 13.98 \\
& 2 & 1991 & $44.96^{*}$ & 15.72 \\
\hline Lesotho & 1 & 1977 & $117.63^{*}$ & 13.98 \\
& 2 & 1998 & $33.29^{*}$ & 15.72 \\
& 3 & 2009 & $20.13^{*}$ & 16.83 \\
\hline Namibia & - & - & 13.37 & 13.98 \\
\hline eSwatini & 1 & 1985 & $131.17^{*}$ & 13.98 \\
& 2 & 2010 & $21.41^{*}$ & 15.72 \\
\hline South Africa & 1 & 1977 & $249.99^{*}$ & 13.98 \\
& 2 & 2000 & $25.73^{*}$ & 15.72 \\
& 3 & 1985 & $32.52^{*}$ & 16.83 \\
\hline
\end{tabular}

Source: own computations based on data from World Development Indicators (2019). * indicates statistical significance at 0.05 level.

\section{Author}

\section{Malefa Rose Malefane}

$\mathrm{PhD}$ in Economics (University of South Africa). Her research interests include international trade and economic growth - focusing on trade policy and the effects of economic integration in emerging economies.

Correspondence to: Dr Malefa Rose Malefane, PhD, University of South Africa, Department of Economics, Anton Lembede Building Room 4-41, Pretoria, 0003, South Africa, e-mail: malefmr@unisa.ac.za ORCID (1) http://orcid.org/0000-0002-1644-957X

\section{Acknowledgements and Financial Disclosure}

The author would like to thank the Economic Research for Southern Africa (ERSA) for their training in econometrics, which improved the value of this article.

\section{Conflict of Interest}

The author declares that the research was conducted in the absence of any commercial or financial relationships that could be construed as a potential conflict of interest.

\section{Copyright and License}

This article is published under the terms of the Creative Commons

Attribution - NoDerivs (CC BY-ND 4.0) License

http://creativecommons.org/licenses/by-nd/4.0/ 
